\title{
Research on Procuratorial Organs Bringing Environmental Public Interest Litigation
}

\author{
Zheni Liang ${ }^{1}$ \\ ${ }^{1}$ Law School of Beijing Normal University, Beijing, China \\ Correspondence: Liang Zhe-ni, Law School of Beijing Normal University, No. 19, XinJieKouWai St., HaiDian \\ District, Beijing 100875, P. R. China .Tel: 86-131-6108-0600. E-mail: 810956174@qq.com
}

Received: February 24, 2019

Accepted: March 3, 2019

Online Published: March 29, 2019

doi:10.5539/ass.v15n4p108

URL: https://doi.org/10.5539/ass.v15n4p108

\begin{abstract}
The procuratorial organ is a state supervisory authority and has the power of legal supervision. Giving the procuratorial organs the qualifications for public interest litigation not only has a theoretical basis but also a realistic basis, which helps to solve the problem of difficult evidence collection and high litigation costs in environmental public interest litigation. In the civil environmental public interest litigation, the procuratorate has the dual status of the plaintiff and the legal supervisor, and will not naturally conflict with each other. However, due to the special nature of environmental problems, the relevant administrative departments should be given priority to the environmental problems discovered by the procuratorial organs. Only when the environmental protection supervision departments are exercising their powers, should the procuratorial organs initiate environmental public interest litigation. For civil environmental public interest litigations that have been criminally sentenced or are in the process of criminal prosecution, the procuratorate can make full use of the evidence that has been obtained and identified.
\end{abstract}

Keywords: environmental public interest litigation, procuratorial organs, public interest litigants

In recent years, China's environmental pollution incidents have occurred frequently, and the environmental damage caused by it has been shocking. According to the "2015 China Environmental Status Bulletin", the proportion of acid rain cities in China is $22.5 \%$, and the average frequency of acid rain is $14.0 \%$. Among the 5118 groundwater quality monitoring points, the proportion of monitoring points with good water quality is only 9.1\%. Strengthening environmental protection is an urgent task. The Civil Procedure Law of the People's Republic of China, revised in 2012, adds a public interest litigation clause in its legislative provisions. For conduct that pollutes environment, infringes upon the lawful rights and interests of vast consumers or otherwise damages the public interest, an authority or relevant organization as prescribed by law may institute an action in a people's court. This pioneering work was hailed by the media as "opening a door for environmental public interest litigation" and "making China's public interest litigation system a big step in breaking the ice of the legal system".

Compared with other lawsuits, environmental civil public interest litigation mostly has the characteristics of wide range of victims, large number of people, serious victimization results, and huge interests. At the same time, it is difficult for each victim to specifically quantify the environmental damage. If a lawsuit is filed, it requires a large amount of investment in human, financial and material resources, and it faces a great risk of losing. Taking forensics as an example, the cost of forensics in environmental public interest litigation is as low as several hundred thousand yuan, and it is likely to be several million yuan and ten million yuan. Although according to the Interpretation of the Supreme People's Court on Several Issues concerning the Application of Law in the Conduct of Environmental Civil Public Interest Litigations, after winning the case, the plaintiff may request the fee to be changed by the defendant, but once lost, the plaintiff needs to bear a very high litigation cost. And the cost of forensics often requires the plaintiff to advance, but for social organizations that sue environmental civil public interest litigation, especially civil society organizations, this cost is likely to make it difficult to enter the proceedings.

Therefore, many scholars and scholars have proposed that the procuratorial organ should file an environmental civil public interest litigation. Although according to the Measures for the Implementation of the Pilot Program of Initiating Public Interest Actions by People's Procuratorates, which stipulates that the procuratorate can 
initiate civil environmental public interest litigation for environmental pollution problems found in the course of performing its duties, there is still much room for discussion for the procuratorial organ to initiate civil environmental public interest litigation.

\section{The Theoretical and Practical Basis for the Procuratorate to Raise Civil Environmental Public Interest Litigation}

The traditional entity party theory holds that the parties in a civil lawsuit should be the subject of the entity's rights and obligations in dispute, and it is closely related to the case and litigation and the civil rights of the subject. The basic feature of the theory is that the parties and the case have "direct interests", and those other than the direct interested parties cannot become parties to the case. The party system determined in China's Civil Procedure Law is established under the guidance of the entity's theory. Therefore, it is generally believed that the issue of the determination of the parties in the Civil Procedure Law of China is based on the traditional interest parties.

If it is based on the "interested parties", then the procuratorial organ obviously does not have the qualification to file a civil environmental public interest litigation. However, with the development of modern litigation rule of law and litigation theory, the theory of procedure parties, the interests of litigation, litigation trusts and other theories provide a justification for this subject to raise civil environmental public interest litigation. The theory of the procedure parties holds that: "The litigant is a procedural concept. It is judged whether the litigant is qualified. It is only necessary to see who is the prosecutor and whether he has the right to appeal (procedural right of action) without having to examine the relationship between the litigation subject and the substantive law. That is to say, the parties may not be interested parties." (Note 1) The theory of interest claims that "the plaintiff does not have a direct interest relationship with the case, but the interest is not exclusive or shared by the plaintiff. The interests of the litigation are not actually controlled by the plaintiff. That is, there is an interest that differs from the direct interest." (Note 2) The litigation trust theory emphasizes on the basis of public trust: "In order to protect the national interest and the public interest of the society, it is necessary to have a 'speaker' as the party to file a lawsuit in its own name. The spokesperson is not a direct interested party, but also the subject matter of the litigation. Without the legitimate interests, it only enjoys the right to appeal in the procedural sense based on the 'trust' of the entity right holder, and initiates the lawsuit in its own name and undertakes the litigation result in the procedural sense. This trust is generated based on legal provisions." (Note 3)

Based on the above theories, the academic circles have the following views on the legal basis of the public prosecution of public prosecution: The "public interest representative" believes: "It is necessary to set up a body that can represent the public interest and has sufficient effective legal means and authority to initiate litigation and participate in litigation on behalf of the state". (Note 4) From this perspective, the procuratorate is undoubtedly the best subject. The "legal supervisory authority" theory holds that: "The procuratorial organ, as the state's legal supervisory organ, should supervise the compliance of public welfare laws. If public welfare laws are violated, but no subject has filed a corresponding lawsuit, this is actually negated. The role of public welfare law." The "public prosecutor" theory holds that "the prosecutorial authority's right to public prosecution is first formed in the state prosecution of criminal acts, but the prosecution of criminal offences can not contain all forms of the exercise of public prosecution." (Note 5) This theory advocates that the scope of the public prosecution is determined by whether it is a public interest. Although the arguments of the above-mentioned doctrines are different, from the point of view of the responsibilities of the procuratorial organs stipulated in the Constitution, the procuratorial organs are the state's legal supervisory organs and have the power to supervise the law. The procuratorate not only has supervisory power over criminal proceedings, but also has supervisory power over administrative litigation and civil litigation. At the same time, the procuratorial organs can also intervene in civil proceedings at any stage, and can file civil suits. This can be said to lay a solid legal basis for the procuratorial organs to raise environmental public interest litigation.

In addition to theoretical support, the procuratorial organs have a very realistic basis. As mentioned above, the cost of litigation for environmental public interest litigation is too large for social organizations, and the procuratorial organ's environmental public interest litigation can solve this problem. Moreover, the procuratorate also has the statutory power of evidence investigation, which can solve the difficult problem of obtaining evidence in environmental public interest litigation. For example, in 2015, the Dalian Environmental Protection Volunteers Association filed an environmental public interest lawsuit against the Dalian Marine Court against the marine environmental pollution caused by the 7.16 crude oil leakage of PetroChina. Although the parties reached a mediation agreement in the final case, the Dalian Environmental Protection Volunteers Association said during the litigation process. "The biggest difficulty is obtaining evidence, and the relevant administrative departments are unwilling to cooperate." "The association has collected some data and materials, which is far from enough. 
For example, the biological pollution of the bottom, the pollution of the beach, etc., also requires the functional departments to provide data. But after going there, it is not possible." The Marine Environmental Protection Department of the Dalian Ocean and Fisheries Bureau stated that "the marine fisheries sector can support and provide data that can be provided, but some data are not available. In addition, due to lack of clear support regulations, some data are marine fisheries. The department is also unable to provide it." If the procuratorial organ is allowed to file an environmental public interest litigation, the procuratorial organ may obtain relevant data of the case in accordance with the law and solve the problem of difficulty in giving evidence in environmental public interest litigation.

\section{The Identity Orientation of Procuratorial Organs in Public Interest Litigation}

In the environmental civil public interest litigation filed by the procuratorate in the capacity of the plaintiff, is there a problem of conflict between the legal supervisor and the plaintiff. Some scholars have proposed that, from the perspective of the balance of civil litigation structure, if the procuratorial organ participates in civil litigation as a legal supervisor, both the defendant and the court are the objects of supervision, which will distort the structure of civil litigation, make the purpose of civil litigation structure mere formality, and damage the construction mode of civil litigation. (Note 6) At present, the Measures for the Implementation of the Pilot Program of Initiating Public Interest Actions by People's Procuratorates positions the procuratorate as a "public interest litigant" to distinguish it from the litigants in the usual sense. However, the specific connotation of "public interest litigants" has not yet been clarified, and there is a divergence in the understanding of the academic community. Some scholars believe that the procuratorial organs also play the role of the parties and the legal supervisors. "The procuratorial organs are special plaintiffs of public interest litigation. They enjoy the legal supervision functions stipulated by the Constitution and have certain specialities in their identity." (Note 7) The identity and status of the procuratorial organs in public interest litigation are twofold: on the one hand, the civil public prosecutor or the administrative public prosecutor belongs to the litigant in the litigation, enjoys the litigation rights that the litigant should have, and bears the litigation obligations of the litigant. On the other hand, the civil public prosecutor or the administrative public prosecutor is the supervisor in the litigation. It has the right to be fair and efficient in public interest litigation and the court's neutral objective judgment on public interest litigation has the right to legal supervision. (Note 8) Of course, some scholars hold different views. They believe that the legal supervisor cannot perform an equal function with the people's court as the supervised person when performing the supervisory function. Moreover, the supervisor cannot have his own interests in the matters supervised. The procuratorial organs enjoying the civil public prosecution will inevitably have the 'self-interest' to pursue the outcome of the public interest litigation, and therefore oppose the procuratorial organ's function of litigation supervision in civil public interest litigation.

Although the procuratorate has the dual status of the plaintiff and the legal supervisor in the civil environmental public interest litigation, this does not mean that the two roles will inevitably conflict. In criminal proceedings in China, the procuratorial organs also have dual identities. On the one hand, the procuratorial organs are state prosecutors, prosecuting on behalf of the state, and safeguarding the life safety of the people's property. On the other hand, the procuratorate is also the supervisor of the law, supervising the implementation of criminal law and the legality of the court's criminal trial activities. This provides a paradigm for the procuratorial organs to play a dual role in civil public interest litigation.

\section{Relationship Between Procuratorate and Environmental Protection Authority}

With the globalization and risk of modern society, environmental pollution and ecological problems are no longer a single source, a single time and space, but a multi-source, long-latency, and cross-regional characteristics. These changes pose greater challenges to the identification of damage facts and causal relationships. The courts focus on post-hoc relief and can only refer to individual cases, which leads to the inability of the judiciary to function to prevent environmental problems. In this context, around the 1970s, various countries responded to increasingly prominent environmental problems by establishing specialized environmental protection departments or giving other departments environmental protection responsibilities to strengthen administrative enforcement. China promulgated the Environmental Protection Law of the People's Republic of China (For Trial Implementation) in 1979. Since then, more than 30 laws on environmental and resource protection have been issued, and relevant administrative regulations and departmental regulations are countless. The administrative agency has professional personnel and special financial input in the field of environmental protection, and has the professional knowledge and skills in environmental protection. Therefore, it has great advantages in implementing all-round protection of the environment. However, one of the major problems facing the environmental protection department is that the results are not satisfactory and therefore have been questioned. At present, the problem of environmental protection in China lies in the specific design of 
the environmental protection system and the constraints of the operating environment of the system, rather than the administrative power itself. Therefore, the administrative law enforcement power cannot be replaced by the judicial power. The Environmental Protection Law of the People's Republic of China (2014 Revision) also holds this attitude.

In the judicial practice of China, administrative means are not always able to solve the problem of environmental pollution. In some cases, the administrative organs still need to rely on judicial power. For example, Dongtai Environmental Protection Bureau and Lu Zhijun, Zibo Chicheng Transportation Co., Ltd. Zhangdian Branch, China Ping An Property Insurance Co., Ltd. Zibo Center Branch, Sunshine Property Insurance Co., Ltd. Zibo Center Branch Motor Vehicle Traffic Accident Liability Dispute Case. (Note 9) In March 2013, Lu drove a heavy-duty semi-trailer truck/hanging heavy-duty tank semi-trailer with a chloropropene owned by a transportation company owned by Zibo, and did not follow the traffic lights. He drove a heavy-duty semi-trailer with Wang. / Hanging heavy ordinary semi-trailers collided, causing a large amount of leakage of vinyl chloride, causing damage to road facilities, farmland and environmental pollution. The Dongtai Environmental Protection Bureau promptly dealt with the pollution caused by the leakage of chloropropene and incurred related expenses. Therefore, it filed a lawsuit with the court to claim compensation for the corresponding losses. The court held that the plaintiff had exempted the unspecified population after causing environmental pollution. Due to the damage caused by the leakage of chloropropene, the pollutants caused by the leakage of chloropropene have been treated, and the public welfare is concerned. The related expenses of the expenditure are related to the expenses incurred by the public welfare behavior, which is in line with the provisions of public interest litigation. The court finally supported the litigation request of the Dongtai Environmental Protection Bureau. Some scholars believe that: "Even if the administrative means are exhausted, the damage to the state-owned environmental resources cannot be fully compensated. The legal protection of property rights includes administrative relief, civil remedies and criminal sanctions. No one of them can provide complete protection. The design of legal liability is to make them complementary." (Note 10) Investigating China's current civil environmental public interest litigation and environmental pollution in China, only a very small number of cases have been brought to court. In most cases, the offenders have escaped legal sanctions and environmental losses also failed to get adequate relief. Therefore, in order to solve this problem, the procuratorate should be allowed to use judicial means to provide the necessary assistance to protect environmental resources under appropriate conditions.

However, as mentioned above, the environmental protection administrative organs are more professional, and the special attributes of environmental issues determine the necessity of administrative dominance. Therefore, the issue of environmental pollution involving public interest should be treated preferentially by the environmental protection supervision department using administrative means. Only when the environmental protection supervision department is incapable of exercising its power or its administrative means is difficult to be effective, the procuratorial organ can initiate environmental public interest litigation. According to the Measures for the Implementation of the Pilot Program of Initiating Public Interest Actions by People's Procuratorates, it must supervise and urge the organs prescribed by law to file civil public interest litigation before the people's procuratorate filed a civil public interest litigation. Only after the pre-litigation procedure, the organs prescribed by law have not filed a civil public interest litigation and the public interest is still in the state of being infringed, the people's procuratorate may file a civil public interest litigation.

If the competent department of environmental protection receives the prosecutorial opinion from the procuratorate, it is considered that the use of administrative means is more beneficial to the protection of the public interest, and administrative measures have been taken. However, the problem has not been fully resolved and the public interest is still being violated. At this time, can the procuratorate file a civil environmental public interest litigation? This paper believes that the procuratorial organ should judge the feasibility of the environmental protection authorities by virtue of the understanding of relevant environmental legislation and administrative legislation. If it is feasible, it should not file a civil environmental public interest litigation, but the administrative organ should inform the inspection of the administrative treatment opinions. The authorities shall prevent the procuratorial organs from filing environmental public interest litigation without knowing the circumstances and waste judicial resources.

\section{On the Problems Raised by the Procuratorial Organs in Raising Environmental Public Interest Litigation and Suggestions for Improvement}

\subsection{The Scope of the Case Prosecuted by the Procuratorate}

According to the Measures for the Implementation of the Pilot Program of Initiating Public Interest Actions by 
People's Procuratorates, the procuratorial organs can only file civil environmental public interest litigation against the environmental pollution problems found in the course of performing their duties, which harms the public interest of the society. However, due to the high cost of public interest litigation in civil environment, social organizations may not be able to raise civil environmental public interest litigation, and environmental pollution problems often involve the interests of local governments. Therefore, in some cases, it is difficult to rely entirely on administrative agencies to bring environmental public interest litigation to provide relief. At this time, for the public who is harmed, if it can only be resolved by private interest litigation, it is difficult to effectively protect the public interest. This paper suggests that the procuratorial organ may choose whether to file an environmental public interest litigation against public environmental pollution problems involving public interest. The procuratorial organ refuses to sue, it should be reasonably stated. In order to prevent the procuratorial organ from exercising its right, the public or social organization has the right to request the procuratorial organ to review it.

For some cases that seriously damage or threaten the public interest of the environment, because of the wide scope of the case, the large number of people involved, the large amount, and the serious consequences, if the civil environmental public interest litigation is initiated by a relatively weak social organization, it is not conducive to protecting the environment. Especially in the case of the inaction of the administrative agency, only the powerful and professional procuratorial organs can compete with the illegal enterprises. If at this time, it is obviously inappropriate to limit the scope of prosecution of procuratorates to environmental pollution behaviors that are harmful to the public interest of the public during the performance of duties. Therefore, for such cases, the procuratorial organ should be obliged to file a civil environmental public interest litigation. If the procuratorate is reported by the public or social organizations, it shall file a civil environmental public interest litigation. The reason for this is to prevent the prosecutorial agency from selectively prosecuting. Because of this phenomenon in judicial practice, most of the prosecution authorities are small private enterprises that have less impact on the environment, and relatively few public interest litigations against large enterprises.

\subsection{Procuratorate's Right to Impose Environmental Public Interest Litigation}

The civil environmental public interest litigation plays an extremely important role in protecting environmental resources and safeguarding the public interest. However, the cost of civil environmental public interest litigation is extremely huge. Every civil environmental public interest litigation requires the investigators and the court to invest huge manpower, material resources and financial resources, especially the civil environmental public interest litigation brought by the procuratorial organs. It is even more necessary for the state to pay the litigation costs. If the environmental protection authority can exercise the administrative power in time, the offender can correct his behavior in time, which can save a lot of cost. Therefore, it is necessary to restrict the prosecutorial authorities from filing civil environmental public interest litigation.

The United States has set up a pre-notification procedure that requires the prosecutor to notify the offender before the prosecution. If the offender corrects the violation within the prescribed time limit, the right of action will be prevented. The Measures for the Implementation of the Pilot Program of Initiating Public Interest Actions by People's Procuratorates also stipulates that the procuratorial organ must notify relevant departments or social organizations before filing a civil environmental public interest litigation. However, the purpose of this regulation is only to urge the procuratorate to remedy environmental problems when there is no suitable subject or the eligible subject is unwilling to file a lawsuit, not to stop the lawsuit. Therefore, it is different from the US pre-notification procedure.

The paper believes that the object of notification should not be limited to the environmental protection authorities, but should also include their superiors and other departments with environmental protection supervision duties. Article 57 of the Environmental Protection Law of the People's Republic of China stipulates: Citizens, legal persons, and other organizations that discover any environmental pollution or ecological damage caused by any entity or individual shall have the right to report to environmental protection administrative departments or other departments with environmental protection supervision and administration functions. Article 67 stipulates: The people's governments at higher levels and the environmental protection administrative departments thereof shall strengthen supervision over the environmental protection work of the people's governments at lower levels and the relevant departments thereof, and, if they discover that any employees have committed any illegal acts for which disciplinary actions shall be taken according to the law, recommend disciplinary actions to the appointment and removal authorities or supervisory authorities for such employees. When the local government and its environmental protection authorities fail to perform their duties according to law, their superior authorities or supervisory organs are obliged to accept reports and take measures to correct illegal administrative actions. Therefore, the procuratorial organ should notify the competent department of 
environmental protection to perform its statutory duties for the environmental pollution problem that the procuratorate receives from the report or the performance of its duties that harms the public interest. If it later performs its duties and supervises the environmental pollution problem according to law, the procuratorial organ does not need to file a civil environmental public interest litigation. If it fails to perform its duties, the procuratorate may report it to its superior authority. Before the procuratorial organ files a civil environmental public interest litigation, it should solve the problem through administrative means as much as possible to save judicial costs.

\subsection{The Connection Between Public Interest Litigation and Criminal Litigation in Civil Environment}

For a long time, the procuratorial organs have cracked down on criminal acts by performing criminal prosecution functions and protected the public interest of the country. However, the criminal prosecution object of the procuratorial organ is limited to the act that constitutes the crime, and the crime constitutes a higher requirement for social harm and illegal circumstances, which leads to a large number of illegal acts cannot be sanctioned through criminal prosecution. However, although the role of criminal public prosecution in maintaining the public interest of the environment is limited, it is still of great significance for deterrence crime and crime prevention. Therefore, it is necessary to clearly arrange the connection between environmental criminal prosecution and civil environmental public interest litigation in the system.

For this issue, we can also refer to the United States. The US Federal Environmental Protection Agency can transfer the case to the Federal Ministry of Justice to initiate criminal proceedings against the offender in order to implement environmental laws. In the United States, environmental offenders are not only subject to fines or imprisonment sanctions, but may also be ordered to cover the environmental damage they cause. For example, a criminal may be ordered to pay the local fire department for the cost of cleaning up hazardous waste. Criminal Law of the People's Republic of China stipulates the crime of polluting the environment and illegally disposing of imported solid waste. It also stipulates the penalty method of fines. However, the fines stipulated in the Criminal Law are not based on the complete compensation for environmental damage, and often do not adequately relieve environmental damage. Even if a criminal incidental civil action can be filed, it can only provide relief for individual victims. The criminal acts that are harmless to the environment itself are incapable. The crimes caused by the crimes are incapable of harming the environment itself, and the procuratorate found that the clues of the environmental public interest litigation cases were discovered during the performance of the duties. The civil environmental public interest litigation brought by the procuratorial organs at the same time polluting the environment is likely to constitute a crime. For example, in the case of Changzhou City Procuratorate v. Xu Jianhui and Xu Yuxian polluting the environment, Xu Jianhui and Xu Yuxian did not apply for industrial and commercial business licenses and hazardous waste business licenses, and arbitrarily engaged in the cleaning business of waste resin barrels and waste oil barrels, and illegal discharge and Dispose of waste water and waste residue after washing. After being investigated and handled by the public security organs, the qualified units were entrusted to take samples for testing. A variety of toxic substances were detected in the solid waste samples and residues in the plant plots. The groundwater in the site was polluted, and various heavy metals and organic matter in the water exceeded the standard. Later, Xu Jianhui and Xu Yuxian were investigated for criminal responsibility for environmental pollution crimes, but environmental damage has not been repaired. In 2015 , the procuratorate found clues in the case in the performance of its duties, and filed a case review on the case. After the appraisal and assessment of Changzhou Environmental Science and Technology Co., Ltd., the cost of pollution remediation reached 3.562 million yuan. The Changzhou Municipal Procuratorate believes that $\mathrm{Xu}$ Jianhui and Xu Yuxian's illegal disposal of toxic substances seriously pollute the environment and harm the public interest. In the case of no suitable public interest litigation subject in Changzhou City, a civil public interest litigation was filed with the Changzhou Intermediate People's Court, requesting Xu Jianhui and Xu Yuxian to dispose of the hazardous waste left in the site in time to eliminate the danger. Xu Jianhui and $\mathrm{Xu}$ Yuxian were ordered. Remediate the contaminated soil in time and restore the original condition.Xu Jianhui and $\mathrm{Xu}$ Yuxian were ordered to compensate for the cost of repairing the environmental impact of the site's sewage discharge. Based on the virtual treatment cost of 300,000 yuan, the compensation was calculated based on the environmental sensitivity of the region by 4.5-6 times. The amount is paid to the special account of Changzhou Environmental Public Welfare Fund. Finally, the court ordered $\mathrm{Xu}$ Jianhui and $\mathrm{Xu}$ Yuxian to clean up and dispose of the 130 waste barrels left in the washing bucket, the sewage and bottom sludge accumulated in the two sewage pools, and the residues piled up in the plant area. To eliminate the danger of continued pollution of the environment and entrust a unit with soil treatment qualifications to formulate a soil remediation plan, submitted to the Changzhou Environmental Protection Bureau for approval and implementation within two months; compensation for environmental restoration costs of 1.5 million yuan, paid to Changzhou 
Environmental Public Welfare Fund-specific account.

It can be seen that criminal litigation is not satisfactory in the relief of environmental public welfare damage, and it is necessary to file an environmental public interest litigation separately. As most of the cases that constitute crimes will seriously damage or threaten the public interest, as mentioned above, the procuratorate also filed an obligation for civil environmental public interest litigation. Moreover, from the practical level of operation, the standard of proof of criminal evidence requires "to exclude the degree of reasonable doubt." If the conviction can be convicted, the procuratorate has already obtained sufficient evidence to save the environmental public interest litigation. The most complicated links such as forensics and identification are extremely convenient for bringing out environmental civil public interest litigation.

However, at present, relevant laws and judicial interpretations do not stipulate the coordination and cooperation between criminal litigation and civil environmental public interest litigation. Therefore, this paper suggests that the procuratorial organ may be required to provide civil environmental public welfare for environmental cases that have been criminally imprisoned or are in the process of criminal prosecution. Litigation can make full use of the evidence that has been obtained and identified. Therefore, this paper suggests that the procuratorial organ can be required to make full use of the evidence that has been obtained and identified for civil environmental public interest litigation that has been criminally imprisoned or is in the process of criminal prosecution.

\section{Notes}

Note 1. Guo, Y.-H. (2005). LI Qing-hua: On Qualified Plaintiff in the Environmental Suit of the Public Benefit. Hebei Law Science, (5).

Note 2. Xu, X. M., \& Ji, X. X. (2009). Powers and Functions of Courts to Accept Environmental Public Interest Litigation Under the Present Judicial System. Journal of Ocean University of China (Social Sciences Edition), (5).

Note 3. Chen, X. P. (2005). On the Justifiable Basis upon which the Prosecutor' Offices Bring Action into the Court-From the Angle of Litigation Trust. Law Science Magazine, (4).

Note 4. Jiang, W. (2005). A Brief Discussion on the Exercise of Prosecutorial Supervision Power in Civil Litigations. People's Procuratorial Monthly, (18).

Note 5. Sun, H. K., \& Tao, B. J. (2015). The Dual Observation of Procuratorial Organs Participating in Environmental Public Interest Litigation-Concurrently on the Perfection of Article 55 of Civil Procedure Law. Oriental Law, (3).

Note 6. Yang, G. P. (2014). Thoughts on Procuratorial Organs Participating in Public Interest Litigation. Hubei Social Sciences, (5).

Note 7. Xiao, J. G. (2015). Procuratorial organs should pay attention to two issues when filing civil public interest litigation. People's Procuratorial Semimonthly, (14).

Note 8. Tang, W. J. (2015). Analysis of issues related to the procuratorial organ's pilot of public interest litigation. Chinese Cadres Tribune, (8).

Note 9. Dongminchuzi No. 0122. (2014).

Note 10. Li, Y. P., \& Zhan, S. M. (2011). Waters: Pollution Public Interest Litigation in Practice-Guangzhou Maritime Trial Related Cases (1991 2009). Sun Yat-sen University Law Review, 1.

\section{Copyrights}

Copyright for this article is retained by the author(s), with first publication rights granted to the journal.

This is an open-access article distributed under the terms and conditions of the Creative Commons Attribution license (http://creativecommons.org/licenses/by/4.0/) 